\title{
Galectin-1 Regulates Initial Axonal Growth in Peripheral Nerves after Axotomy
}

\author{
Hidenori Horie, ${ }^{1}$ Yoshimasa Inagaki, ${ }^{4}$ Yoshiaki Sohma, ${ }^{4}$ Risa Nozawa, ${ }^{4}$ Katsuya Okawa, ${ }^{5}$ \\ Mitsuhiro Hasegawa, ${ }^{6}$ Naoki Muramatsu, ${ }^{6}$ Hitoshi Kawano,, ${ }^{7}$ Masao Horie, ${ }^{7}$ Hiromichi Koyama, ${ }^{3}$ Ikuko Sakai, ${ }^{1}$ \\ Kaori Takeshita, ${ }^{1}$ Yuki Kowada, ${ }^{1}$ Masahiko Takano, ${ }^{2}$ and Toshihiko Kadoya ${ }^{4}$
}

Departments of ${ }^{1}$ Physiology and ${ }^{2}$ Ophthalmology, School of Medicine, and ${ }^{3}$ College of Nursing, Yokohama City University, Kanazawa-ku, Yokohama 236-0004, Japan, 4Pharmaceutical Research Laboratory, Kirin Brewery Co., Ltd., Takasaki 370-1295, Japan, ${ }^{5}$ Central Laboratories for Key Technology, Kirin Brewery Co., Ltd., Kanazawa-ku, Yokohama 236-0004, Japan, ${ }^{6}$ Department of Neurosurgery, Kanazawa University School of Medicine, Kanazawa 920-0934, Japan, and 7 Department of Anatomy and Embryology, Tokyo Metropolitan Institute of Neuroscience, Fuchu,

Tokyo 183-8526, Japan

The signals that prompt the axons to send out processes in peripheral nerves after axotomy are not well understood. Here, we report that galectin-1 can play an important role in this initial stage. We developed an in vitro nerve regeneration model that allows us to monitor the initial axon and support cell outgrowth from the proximal nerve stump, which is comparable to the initial stages of nerve repair. We isolated a factor secreted from COS1 cells that enhanced axonal regeneration, and we identified the factor as galectin-1. Recombinant human galectin-1 (rhGAL-1) showed the same activity at low concentrations (50 $\mathrm{pg} / \mathrm{ml}$ ) that are two orders of magnitude lower than those of lectin activity. A similarly low concentration was also effective in in vivo experiments of axonal regeneration with migrating reactive Schwann cells to a grafted silicone tube after transection of adult rat peripheral nerve. Moreover, the application of functional anti-rhGAL-1 antibody strongly inhibited the regeneration in vivo as well as in vitro. The same effect of rhGAL-1 was confirmed in crush/freeze experiments of the adult mouse sciatic nerve. Because galectin-1 is expressed in the regenerating sciatic nerves as well as in both sensory neurons and motor neurons, we suggest that galectin-1 may regulate initial repair after axotomy. This high activity of the factor applied under nonreducing conditions suggests that galectin-1 may work as a cytokine, not as a lectin.

Key words: galectin-1; growth factor; regeneration; nerve transection; nerve crush; peripheral nerve; COS1 cell; organ culture; dorsal root ganglion; axotomy
Initiation of axonal outgrowth after axotomy has been thought to be regulated by neurotrophic factors. Various neurotrophic factors have been demonstrated to improve the rate. The level of NGF mRNA in peripheral nerve increases transiently after axotomy (Heumann et al., 1987; Lindholm et al., 1987). However, axotomy results in the disappearance of high- and low-affinity NGF receptors on the proximal portions of axons of the sciatic nerve, as well as in the dorsal root ganglia (DRGs) in rats (Verge et al., 1989; Funakoshi et al., 1993). The transient increase in NGF mRNA expression after sciatic nerve injury may serve to stimulate the expression of BDNF, which supports motor neuron survival but has not been shown to promote motor nerve regeneration (Yan et al., 1992; Koliatsos et al., 1993; Apfel et al., 1996). Another neurotrophic factor that is found in peripheral nerves is CNTF. However, levels of CNTF and its mRNA decrease dramatically in the nerve after axotomy (Friedman et al., 1992; Sendtner et al., 1992). Unlike the neurotrophic factors shown

\footnotetext{
Received June 29, 1999; revised Sept. 1, 1999; accepted Sept. 8, 1999.

This work was partially supported by a Grant-in-Aid for Scientific Research on Priority Areas of the Japanese Ministry of Education, Science, Sports and Culture. We thank Dr. F.-T. Liu for his kind gift of recombinant human galectin-3 and Dr. Tetzlaff for helpful comments on this manuscript.

Correspondence should be addressed to Dr. Hidenori Horie, Department of Physiology, School of Medicine, Yokohama City University, 3-9 Fukuura, Kanazawa-ku, Yokohama, 236-0004 Japan. E-mail: horiehd@med.yokohama-cu.ap.jp.

Copyright (C) 1999 Society for Neuroscience 0270-6474/99/199964-11\$05.00/0
}

above, the insulin-like growth factor-I (IGF-I) expression was significantly increased after transection of the sciatic nerve (Hansson et al., 1986; Glazner et al., 1994), and perfusion of anti-IGF-I antibodies inhibits the regeneration of crushed sciatic nerve (Kanje et al., 1989). However, because IGF-I mRNA content at the site of injury increases 4 and $6 \mathrm{~d}$ after nerve crush $(\mathrm{Pu}$ et al., 1995), the signals that prompt the axons to send out processes in peripheral nerves after axotomy are not well understood.

There should be a factor to regulate initial repair in peripheral nerves after axotomy. A strategy to find this factor is essential to clarify the initial events occurring in the proximal site. There have been many reports of successful discoveries of essential neurotrophic factors from cultured cell conditioned media (LeviMontalcini and Hamburger, 1951; Barde et al., 1978; Varon et al., 1979; Lin et al., 1993, Kotzbauer et al., 1996). We focused on the kidneys, which secret various essential factors, and used COS1 cells derived from monkey kidney. To identify the factor we introduced an in vitro model for neural regeneration that consists of DRG explant with the associated spinal nerve stump (Horie et al., 1991). The cultured medium of COS1 cells contained an activity to promote axonal regeneration from the transected nerve site of these explant cultures. Here we demonstrate the identification of a factor that promotes axonal regeneration from this nerve stump in vitro and clarify its roles in initial repair after axotomy in vivo. 


\section{MATERIALS AND METHODS}

Preparation of cultured supernatant of COS1 cells. COS1 cells were cultured in IMDM cultured media containing $200 \mu \mathrm{g} / \mathrm{ml}$ BSA, 20 $\mu \mathrm{g} / \mathrm{ml}$ insulin, $20 \mu \mathrm{g} / \mathrm{ml}$ transferrin, $40 \mu \mathrm{M}$ monoethanolamine, and $0.1 \mu \mathrm{M}$ sodium serenite for $3 \mathrm{~d}$. The pooled cultured supernatant $(294 \mathrm{~L})$ was ultrafiltrated with $100 \mathrm{k}$ cutoff membrane, and the filtrate was collected and concentrated with $5 \mathrm{k}$ cutoff membrane (Pall Filtron, Northborough, MA).

Chromatographic procedure. The concentrated cultured supernatant was diluted fourfold with $20 \mathrm{~mm}$ Tris- $\mathrm{HCl}, \mathrm{pH} \mathrm{8.0,} \mathrm{and}$ applied to a TSKgel QAE-Toyopearl 550C (Toso, Tokyo, Japan) column. The bound proteins were eluted with $20 \mathrm{~mm}$ Tris- $\mathrm{HCl}$, $\mathrm{pH}$ 8.0, containing $750 \mathrm{~mm} \mathrm{NaCl}$. Gel filtration was performed on a Sephacryl S200 HR column (Amersham Pharmacia, Uppsala, Sweden) using PBS as eluant. Relative molecular mass $\left(M_{\mathrm{r}}\right)$ was estimated with standard protein markers (Bio-Rad, Richmond, CA). For ion exchange HPLC (IEX-HPLC), a Shodex IEC DEAE-2025 column (Showa Denko, Tokyo, Japan) was used with an elution method of linear gradient of sodium chloride. Reversed-phase HPLC (RP-HPLC) was performed on a YMCpack Protein RP column (YMC, Japan) using a linear gradient of acetonitrile/2-propanol in $0.1 \%$ TFA for elution.

SDS-PAGE and electroblotting. SDS-PAGE was performed with 15-25\% polyacrylamide gradient gel. Prestained protein markers (New England Biolabs, Beverly, MA) were used for electrophoretic estimation of relative molecular mass. After electrophoresis, the proteins were transferred onto a polyvinylidene difluoride (PVDF) membrane with semi-dry electroblotter (Owl Scientific, Woburn, MA).

Molecular cloning of human galectin-1 and construction of pETGall. Human galectin-1 cDNA (Couraud et al., 1989) was isolated from the SuperScript Human Liver cDNA Library (Life Technologies BRL, Grand Island, NY) by nested PCR amplification using the following primers: 5'-TGCGCCTGCCCGGGAACATC-3' (HLEG1; nucleotides 15-34), 5'-GCTGCCTTTATTGGGGGCCA-3' (HLEG6; reverse complement of 472-491), 5'-GAGAGACCATGGCTTGTGGTCTGGTCGC-3' (HLEG14; nucleotides 50-69), and 5' - AGAGTGGATCCTTATCAGTCAAAGGCCACACATTTG-3' (HLEG12; reverse complement of 436-457 in human galectin-1 cDNA; GenBank accession number J04456). The underlined portions were additional sequences designed to generate a NcoI site at the $5^{\prime}$ end (HLEG14) and a BamHI site at the $3^{\prime}$ end (HLEG12), respectively. An initial PCR with HLEG1 and HLEG6 primer was used directly in a second PCR with HLEG12 and HLEG14 primer. Products of the second PCR were digested with $\mathrm{NcoI}$ and BamHI and inserted into the pET-3d vector (Novagen, Madison, WI). This vector allows expression of the corresponding sequence in Escherichia coli cells. The clones obtained (pETGal1) were confirmed by dideoxy sequencing using an automated sequencer (model 377, Applied Biosystems, Foster City, CA).

Expression and purification of rhGAL-1. The cultures of E. coli BL21 (DE3) host strain transformed with pETGal-1 were grown and induced by addition of isopropyl-1-thio- $p$-D-galactopyranoside for protein expression. rhGAL-1 was recovered in the supernatant of sonicated $E$. coli in PBS and purified by IEX-HPLC and RP-HPLC. rhGAL-1 was obtained in high purity, and its concentration was determined by amino acid analysis. The analysis of SDS-PAGE and HPLC showed that the purified rhGAL-1 was not degenerated even after $10 \mathrm{~d}$ incubation at $37^{\circ} \mathrm{C}$ in PBS (5 $\mu \mathrm{g} / \mathrm{ml}$ protein).
Preparation of antibody. An anti-human galectin-1 antiserum was raised in rabbits by an initial subcutaneous injection of $50 \mu \mathrm{g}$ of purified protein from E. coli in complete Freund's adjuvant, followed by five boosts over an 8 week period with $100 \mu \mathrm{g}$ of purified protein in incomplete Freund's adjuvant. The immunoreactivity of antiserum was detected in 1:200,000 dilution in ELISA. The antibody was purified from the serum by affinity chromatography on protein A-Sepharose (Amersham Pharmacia). The specificity of the purified antibody was tested by immunoblotting after SDS-PAGE of rhGAL-1, recombinant human galectin-3, human plasma, and rat sciatic nerve extract. Immunostaining of electroblotted membrane was performed as follows. Anti-rhGAL-1 antibody was biotinylated with EZ-Link SulfoNHS-LC-Biotin (Pierce, Rockford, IL). After incubation with biotinylated anti-rhGAL-1 antibody, immunocomplexes on the membrane were visualized by incubations with alkaline phosphatase-conjugated streptavidin (Dako, Glostrup, Denmark) followed by alkaline phosphatase color development reagents (Bio-Rad). The analysis showed that the antibody reacted with galectin-1 alone.

Assay for axonal regeneration in vitro. Activity of axonal regeneration was detected with a three-dimensional culture of adult rat DRG explant as described previously (Horie et al., 1997). All preparations were obtained from 3-month-old Wistar rats (Nihon SLC). The rats were anesthetized with ether and killed. DRGs (Th-2 to Th-10) of similar size with their associated nerve stumps were carefully dissected and removed. Each DRG with its associated nerve stumps, which were 1.0-2.0 $\mathrm{mm}$ in length, was embedded in a collagen gel. The explants were then cultured at $37^{\circ} \mathrm{C}$ in $95 \%$ air $/ 5 \% \mathrm{CO}_{2}$ in Ham's F12 culture medium supplemented with $5 \mu \mathrm{g} / \mathrm{ml}$ insulin (Sigma, St. Louis, MO), $5 \mu \mathrm{g} / \mathrm{ml}$ transferrin (Sigma), $2 \times 10^{-8} \mathrm{M}$ progesterone (Sigma), $0.1 \mathrm{~mm}$ putrescine (Sigma), and $3 \times 10^{-8}$ M sodium serenite (Sigma). The numbers of regenerating axons from each of these transected nerve ends were counted under a phase-contrast microscope at a region adjacent to the ends before they branched.

Model of sciatic nerve crush/freeze. A total of six female BALB/c mice ( 6 weeks old) were used. They were anesthetized by intraperitoneal injection of chloral hydrate $(5 \%, 0.01 \mathrm{ml} / \mathrm{g}$ body weight) for experiments. The sciatic nerves on a left side were exposed, cleared of connective tissue, and crushed with fine jeweler's forceps at the mid-thigh level. The crushed site was marked with a suture through the epineurium. The nerve-crush/ freeze method (Sjoberg and Kanje, 1989; Rosenbluth et al., 1990; Glazner et al., 1993) was used with minor modification. In brief, the distal nerve section was frozen for $30 \mathrm{sec}$ with forceps that had been chilled in liquid nitrogen and then thawed at room temperature. The freezing and thawing steps were repeated five times, and the freeze-killed nerve was severed $7 \mathrm{~mm}$ distal to the crushed site. For rhGAL-1 treatment, the proximal stump of the severed freeze/thaw-killed nerve was inserted into a polyethylene tube that was connected to an osmotic minipump (Alza Corporation, Palo Alto, CA) and anchored with a suture (Seto et al., 1997). The rhGAL-1 was continuously supplied at $0.5 \mu$ l per hour from the cut end through the polyethylene tube connected to the osmotic minipump, which was implanted subcutaneously on the back. Control animals were treated with saline only. On day 14 after the treatment, the mice were perfused and fixed with $40 \mathrm{ml}$ of $2.5 \%$ glutaraldehyde for electron microscopy in Tris-buffered saline, $\mathrm{pH} 7.4$, containing $1 \mathrm{~mm} \mathrm{CaCl}_{2}$, (TBS-Ca) followed by standard procedure (Hasegawa et al., 1988, 1997). Ultrathin sections were cut on an LKB-2188 ultramicrotome (L.K.B.- 
Produkter, Bromma, Sweden) and examined in an H-600 electron microscope (Hitachi, Tokyo, Japan).

Model of peroneal nerve transection and tubulization. The peroneal nerve was exposed and transected at the mid-thigh level in Wistar rats (3 months old) anesthetized with sodium pentobarbital. The nerve endings were sutured with two 8-0 nylon stitches inside a 7-mm-long silicone tube of $1.0 \mathrm{~mm}$ internal diameter. The silicone tubes had been prepared as follows. One side was closed with a glass bead to prevent cells from invading, and then the inside of the tube was filled with liquid minimum essential medium containing collagen at $0^{\circ} \mathrm{C}$. We examined the four kinds of collagen solutions: (1) control, (2) rhGAL-1 (5 ng/ml), and (3) anti-rhGAL-1 antibody (30 $\mu \mathrm{g} / \mathrm{ml})$ and (4) its control IgG (30 $\mu \mathrm{g} / \mathrm{ml})$. These collagen solutions were converted to a gel phase by warming at $37^{\circ} \mathrm{C}$ for $5 \mathrm{~min}$ (Horie et al., 1997). On day 10 after the treatment, the rats were perfused and fixed with the three fixatives given below. Zamboni solution was used for hematoxylin and eosin (HE) staining and immunohistochemistry with antibodies against S-100 (Dako), $200 \mathrm{kDa}$ neurofilament (Boehringer Mannheim, Mannheim, Germany), and ED1 (Serotec, UK). The second antibodies were shown as follows: fluorescein-conjugated goat $\mathrm{IgG}$ to the antibody against neurofilament (Boehringer Mannheim), rhodamine-conjugated goat $\mathrm{IgG}$ to the antibody against S-100 (Cappel, West Chester, PA), and fluoresceinconjugated goat IgG to the antibody against ED1 (Cappel). Ice-cold acid-alcohol containing 95\% ethanol and 5\% acetic acid was used for HE staining and immunostaining to L1 (kindly supplied by Prof. Uyemura, Keio University, Tokyo) (Miura et al., 1991), PCNA (Novo Castra, UK), and rhGAL-1 (ours). The staining specificity of anti-rhGAL-1 antibody in acid-alcoholfixed paraffin sections was examined by preabsorption tests. Sections were immunostained with preabsorbed anti-rhGAL-1 that had been previously mixed with various concentrations of antigen (rhGAL-1). Addition of $1 \mu \mathrm{g} / \mathrm{ml}$ of antigen to anti-rhGAL-1 (diluted to 1:3000) resulted in the elimination of almost all positive reaction. The third fixative was $2 \%$ paraformaldehyde and $2.5 \%$ glutaraldehyde in $0.1 \mathrm{M}$ sodium cacodylate buffer, $\mathrm{pH}$ 7.4, and was used for transmission electron microscopy. The samples fixed with Zamboni were embedded in Tissue-Tek O.C.T. Compound (Sakura Finetek, CA) and frozen in liquid nitrogen. Cross and longitudinal sections were cut at 10 and 20 $\mu \mathrm{m}$ thickness in a cryostat (Zeiss, Thornwood, NY), respectively, and mounted on silane-coated glass slides. The sections were incubated in primary antibodies and then with a fluorescenceconjugated second antibody. Samples were examined under a Nikon E800 fluorescent optic microscope. Other samples fixed with acid-alcohol were embedded in paraffin after dehydration through absolute ethanol and xylene, sequentially sectioned at 5 $\mu \mathrm{m}$ on a rotary microtome (Mirom H325), and mounted on albumin-coated glass slides. Sections were air-dried on a hot plate at $4^{\circ} \mathrm{C}$ and stored at room temperature. The sections were incubated with the primary antibodies overnight at $4^{\circ} \mathrm{C}$. After rinsing in $20 \mathrm{~mm}$ PBS for $15 \mathrm{~min}$, sections were incubated with secondary antibodies, peroxidase-labeled anti-rabbit IgG Fab' fragments (Medical and Biological Laboratories), for $1 \mathrm{hr}$ at $37^{\circ} \mathrm{C}$. Immunoreactions were visualized in $0.005 \mathrm{M}$ Tris buffer, $\mathrm{pH} 7.4$, containing $0.01 \%$ diaminobenzidine tetrahydrochloride and $0.01 \%$ hydrogen peroxide at $37^{\circ} \mathrm{C}$ for $15 \mathrm{~min}$. Samples for electron microscopy were post-fixed in $2 \% \mathrm{OsO}_{4}$ in the same buffer, dehydrated in graded ethanols, and embedded in epoxy resin. Ultrathin sections were stained with uranyl acetate and lead citrate and were examined at $75 \mathrm{kV}$ in a Hitachi 7500 transmission electron microscope.

Statistical analysis. Statistical analysis of the in vivo and in vitro experiments was performed using Abacus Concepts, StatView for Macintosh (Abacus Concepts). Significant differences between groups were determined by one-way ANOVA, followed by Tukey's post hoc test or by Mann-Whitney's $U$ test. Data are presented as the mean \pm SEM. Values were considered significantly different with $p<0.05$.

\section{RESULTS}

\section{Purification and identification of the COS1-secreted axonal regeneration-promoting factor}

COS1 cells were cultured in IMDM-based serum-free media for $3 \mathrm{~d}$. The cultured medium was applied to a three-dimensional culture of adult rat DRG explants with associated nerve stumps. The medium showed an activity-promoting axonal regeneration from both the central and peripheral transected nerve site of DRG explant cultures (Fig. 1). The COS1-secreted activity was fractionated by a combination of ultrafiltration, ion-exchange chromatography, and gel filtration. The activity was eluted in a fraction corresponding to an $M_{\mathrm{r}}$ between 5,000 and 30,000 by gel filtration. Further purification was performed by IEX-HPLC, RP-HPLC, and SDS-PAGE. An active fraction of RP-HPLC was loaded onto a nonreducing SDS-PAGE. In extraction experiments, the activity was eluted from an SDS-PAGE gel slice corresponding to an $M_{\mathrm{r}}$ of 14,000 protein band only (Fig. 2). After electrophoretic separation, proteins were electroblotted onto a PVDF membrane. Approximately $200 \mathrm{ng}$ of the protein was obtained on the membrane from 294L of COS1 cultured supernatant. The membrane corresponding to the active protein band was cut and processed for internal amino acid sequences by peptide mapping and a sequencer. The three internal amino acid sequences obtained were PGECLRVRGEVA, LPDGYE, and DSNNLCLHFN. A database search showed that the sequences were identical with those of human galectin-1. Galectin-1 is a member of a family of $\beta$-galactoside-binding lectins distributed in the animal kingdom and shows the lectin activity in reduced state (Kasai and Hirabayashi, 1996; Perillo et al., 1998).

For the evaluation of the activity, human galectin- 1 cDNA was isolated from human liver cDNA library by nested PCR amplification, and rhGAL-1 was obtained by expression of the corresponding sequence in E. coli. This rhGAL-1 showed strong promoting activity $(50 \mathrm{pg} / \mathrm{ml})$ of axonal regeneration from transected nerve sites of adult rat DRG explants (Fig. 3). This activity was two orders of magnitude higher than its lectin activity (Mahanthappa et al., 1994). We demonstrated by the inhibition of axonal regeneration using a rabbit polyclonal antibody specific to rhGAL-1 generated in our laboratory (Fig. 3). These results indicate that galectin-1 is necessary for axonal regeneration in the DRG explant. The application of rhGAL-1 to isolated adult rat DRG neurons showed no specific effect on their neurite outgrowth (data not shown). Therefore, we hypothesize that this factor stimulates non-neuronal cells to enhance axonal regeneration from the transected nerve site. On the basis of these in vitro results, we wanted to test whether similar effects of rhGAL-1 are observed in nerve regeneration experiments in vivo. Here we used two kinds of acellular neural regeneration models: first, a nerve crush combined with freezing to the distal stump, and second, a nerve transection and suture of the proximal stump into a deadended silicone tube. 

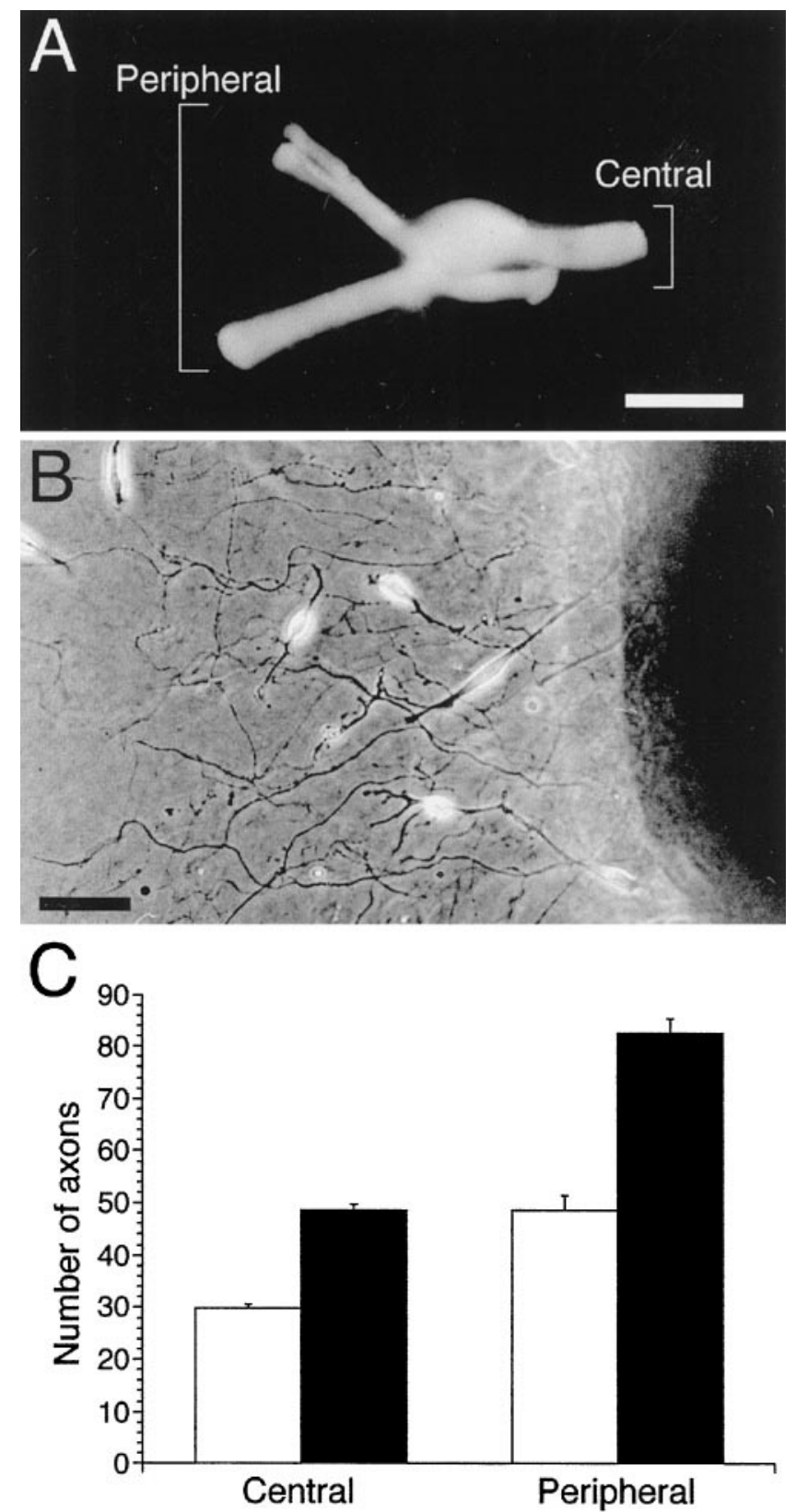

Figure 1. COS1 cells secret a factor to enhance axonal regeneration from transected nerve ends in vitro. $A$, Cultured DRGs with associate nerve stumps that extend in two opposite directions: one bundle extended toward the spinal cord, and the other extended toward sensory organs or muscles. Here, the former is termed the central nerve stump and the latter the peripheral nerve stump. Scale bar, $1 \mathrm{~mm}$. $B$, Regenerating axons from the peripheral nerve end cultured in COS1 cell conditioned medium $6 \mathrm{~d}$ after being in culture. Regenerating axons were counted under a phasecontrast microscope. Scale bar, $50 \mu \mathrm{m}$. C, Bars indicate control ( $\square$ ) and COS1 cell conditioned medium $(\boldsymbol{\square})$. The results represent mean \pm $\mathrm{SEM}=13$ in the control and mean $\pm \mathrm{SEM}=14$ in the COS1 cell conditioned medium. In the central site, $p<0.0001$. In the peripheral site, $p<0.0001$ (ANOVA).

\section{rhGAL-1 promotes migration of reactive Schwann cells engulfing regenerating axons after a nerve crush/freeze in vivo}

Regeneration-promoting effects of rhGAL-1 from crushed mouse sciatic nerves into freeze-killed nerves was examined after continuous delivery of $2.5 \mathrm{ng}$ per hour of rhGAL-1 ( $0.5 \mu$ l per hour)

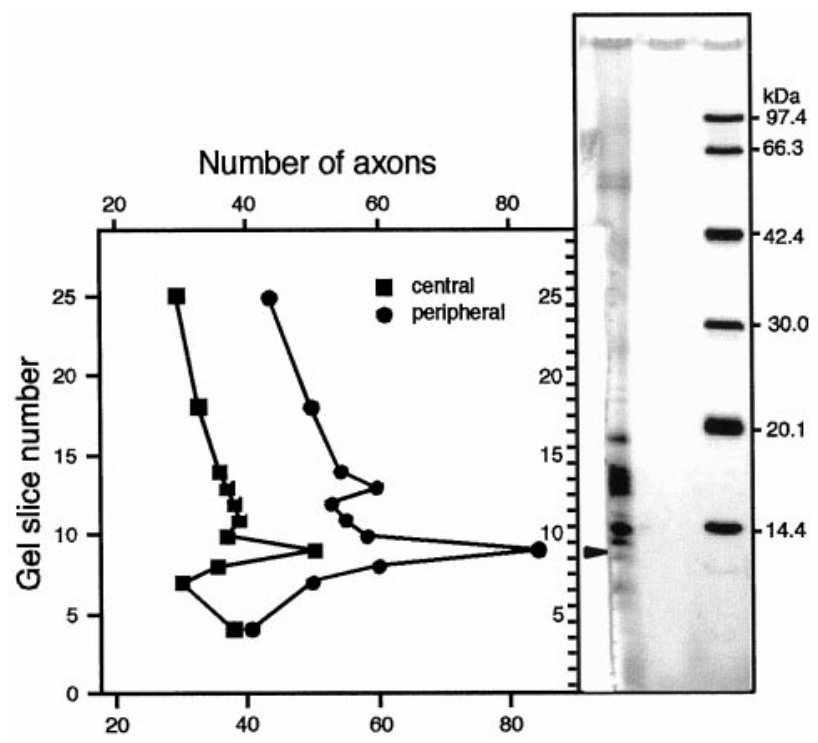

Figure 2. Determination of the factor secreted from COS1 cells. After purification of COS1 cell-secreted neural regeneration-promoting activity, aliquots of the active fraction on RP-HPLC were subjected to SDSPAGE under nonreducing conditions. The gel was separated into two longitudinal semisections, one for silver staining and the other for assay of axonal regeneration-promoting activity. The activity was eluted from a gel slice corresponding to protein band of $M_{\mathrm{r}} 14,000$.

to the proximal stumps $(n=3)$. Control animals were treated with control vehicle PBS $(n=3)$. At $14 \mathrm{~d}$ after the operation, coronal sections at a distance of $6 \mathrm{~mm}$ distal to the crush site were analyzed in the electron microscope. These showed abundant myelin debris and regenerating axons as well as reactive Schwann cells that were identified as bearing basal lamina around their cell membranes (Fig. 4). The Schwann cells migrated among myelin debris and engulfed several regenerating axons. The number of reactive Schwann cells was significantly higher in the rhGAL-1 group $\left(60 \pm 6.8 / 0.015 \mathrm{~mm}^{2}\right.$, mean \pm SEM $)$ than in the control group $\left(1.0 \pm 1.7 / 0.015 \mathrm{~mm}^{2}\right)(p<0.01$; ANOVA $)$, and most of them engulfed regenerating axons in the rhGAL-1 treatment group. These nerve-crush experiments suggest that rhGAL-1 promoted axonal regeneration together with the Schwann cell migration into the acellular nerve.

\section{rhGAL-1 promotes the elongation rate of regenerating axons with migrating Schwann cells after a nerve transection in vivo}

Further analysis of the effect of rhGAL-1 on neural regeneration used the in vivo nerve transection plus tubulization model. Neural regeneration from the nerve transection site of the peroneal nerve into a grafted silicone tube filled with collagen gel was examined in four different conditions: control, $5 \mathrm{ng} / \mathrm{ml} \mathrm{rhGAL-1,} 30 \mu \mathrm{g} / \mathrm{ml}$ anti-rhGAL-1 IgG, and $30 \mu \mathrm{g} / \mathrm{ml}$ control IgG. At $7 \mathrm{~d}$ after operation, double immunostaining of longitudinal sections of frozen regenerated tissues taken from the silicone tubes was performed with anti-neurofilament and anti-S-100 antibodies. The S-100-positive cells were confirmed as Schwann cells by their spindle-like shapes from HE staining. The results showed that the growing axons were accompanied by the Schwann cells, and the tip position of growing axons was identical to that of migrating Schwann cells. This identity may be owing to the slow rate of axonal growth in the acellular axonal regeneration model. Because the tip position of migrating Schwann cells was easily 
A

( I )

(II)

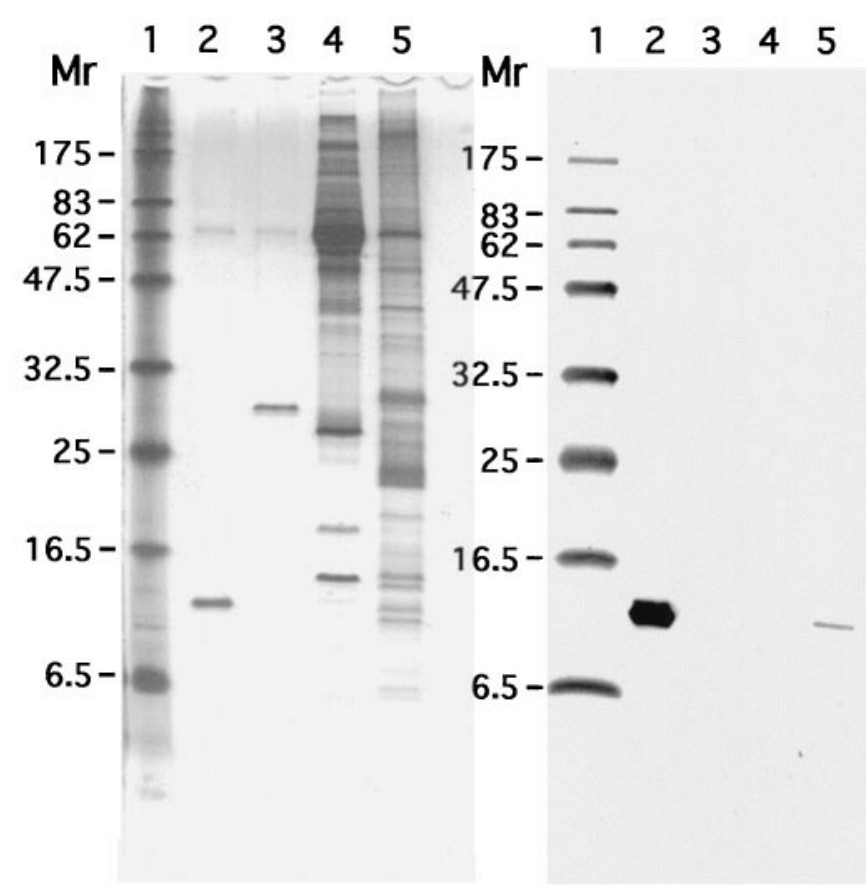

$\mathrm{B}$

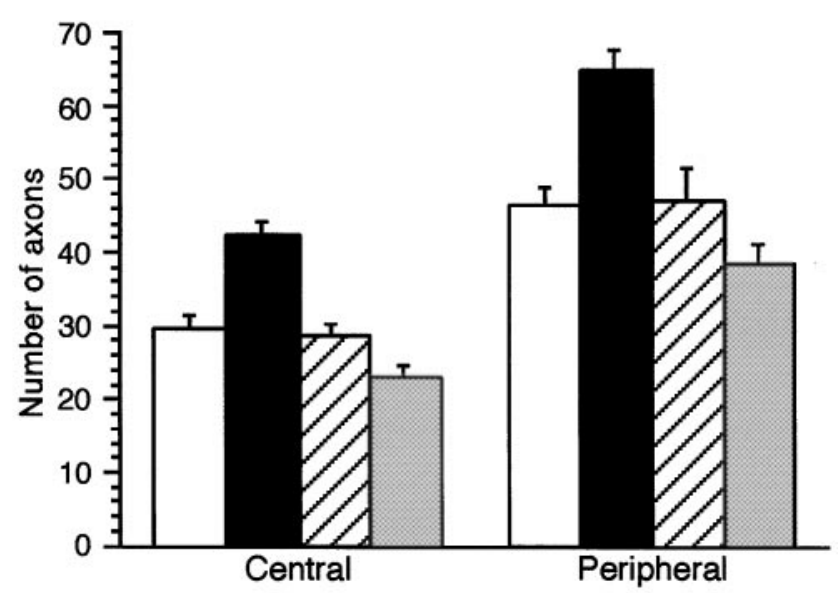

Figure 3. Effects of rhGAL-1 and its antibody on axonal regeneration from transected nerve ends of adult rat DRGs with associated nerve stumps. $A$, Immunoblotting analysis using anti-rhGAL-1 antibody. Samples were subjected to SDS-PAGE under reducing conditions followed by immunoblotting analysis with anti-rhGAL-1 antibody. I, Silver-stained gel; II, immunostained membrane. Lane 1, Prestained protein markers; lane 2, rhGAL-1 (10 ng); lane 3, recombinant human galectin-3 (10 ng); lane 4 , human plasma (2 $\mu$ l of 50 -fold-diluted plasma); lane 5, rat sciatic nerve extract with SDS-PAGE sample buffer. $B$, Regenerating axons were counted under a phase-contrast microscope $6 \mathrm{~d}$ after in culture. Bars indicate control ( $\square$ ), $50 \mathrm{pg} / \mathrm{ml} \mathrm{rhGAL-1} \mathrm{( \square ),} 3 \mu \mathrm{g} / \mathrm{ml}$ control $\mathrm{IgG}$ for anti-rhGAL-1 (田), and $3 \mu \mathrm{g} / \mathrm{ml}$ anti- rhGAL-1 IgG (圈). The results represent mean \pm SEM of 12 in the control, 13 in rhGAL-1, 12 in control $\mathrm{IgG}$, and 14 in anti-rhGAL-1. In the central site, differences between the control and rhGAL-1 and between control IgG and anti- rhGAL-1 were significant $(p<0.0001$ and $p<0.05)$. In the peripheral site, differences between control and rhGAL-1 and between control $\operatorname{IgG}$ and antirhGAL-1 were significant $(p<0.0001$ and $p<0.05)$ (ANOVA). identified in low-magnified pictures (Fig. $5 A-C$ ), we measured the distance of Schwann cell migration instead of that of axonal growth. In this stage, enhancement of Schwann cell migration by galectin- 1 was seen between the control $(0.7 \pm 0.0 \mathrm{~mm}, n=11$, mean \pm SEM $)$ and the rhGAL-1 group $(1.1 \pm 0.0 \mathrm{~mm}, n=5)$ $(p<0.001$; ANOVA). An example of this stimulation of Schwann cell migration at $10 \mathrm{~d}$ after operation is shown in Figure $5 A, B$. Schwann cell migration was $1.2 \pm 0.1 \mathrm{~mm}(n=12)$ in control. When the rhGAL-1 was applied to the gel, Schwann cell migration was expanded to $2.0 \pm 0.1 \mathrm{~mm}(n=11)(p<0.0005$; ANOVA). Magnified pictures around the tip also suggest that a population of regenerating axons along with PCNA-positive Schwann cells were also increased by rhGAL-1 (Fig. $5 a 1, a 2, b 1, b 2)$. These results suggest that rhGAL-1 enhanced both number and growing rate of regenerating axons resulting in a promotion of Schwann cell migration. The essential role of galectin-1 in this axonal regeneration was obvious after treating the collagen gel with anti-rhGAL-1. Figure $5 C$ shows that Schwann cell migration remained at the region near the cut edge of the proximal nerve stump and that other cells migrated beyond the Schwann cells. Higher-power magnifications confirmed that neither Schwann cells nor regenerating axons could be seen around the tip of these migrating cells (Fig. $5 c 1, c 2$ ). Some of the cells were identified as anti-ED-1-positive macrophages but no anti-ED-1-positive cells could be seen near the front in rhGAL1-treated tissues. Schwann cell migration $(0.6 \pm 0.1 \mathrm{~mm}, n=9)$ was particularly shorter than in the treatment of control $\mathrm{IgG}$ gel $(1.2 \pm 0.1 \mathrm{~mm}, n=6)$, whose value was similar to that of the control ( $p<0.05$; ANOVA).

\section{rhGAL-1 increases the number of regenerating axons after a nerve transection in vivo}

Analysis of enhancement of axonal regeneration by rhGAL-1 was performed in cross sections by measuring the number of NFpositive axons in two regions: $0.5 \mathrm{~mm}$ and $1.0 \mathrm{~mm}$ distal to a transected site. At $0.5 \mathrm{~mm}$ the number of axons $(882 \pm 215, n=$ 6 , mean \pm SEM) in the rhGAL-1-treated group was significantly larger than in the control group $(241 \pm 51, n=7)(p<0.05$, Mann-Whitney $U$ test). On the other hand, the number of axons $(72 \pm 35, n=8)$ in the anti-rhGAL-1-treated group was significantly smaller than in the control group $(p<0.05$, MannWhitney $U$ test). As the distance became greater, the number of either regenerating axons or Schwann cells decreased. Figure $6 A 1, A 2$ shows a small number of axons with Schwann cells at the $1.0 \mathrm{~mm}$ site in the control group. On the other hand, in the rhGAL-1-treated group, a larger number of regenerating axons extended to the $1 \mathrm{~mm}$ site and were accompanied by migrating Schwann cells. The number of NF-positive regenerating axons found at $1.0 \mathrm{~mm}$ in the rhGAL-1 $(302 \pm 111, n=6)$ was significantly higher than in the control group $(52 \pm 19, n=7)$ $(p<0.05$, Mann-Whitney $U$ test $)$. This enhancement of the regenerating axon population by rhGAL-1 was clearly seen in the longitudinal sections (Fig. $5 B$ ). On the other hand, the number of axons in the anti-rhGAL- 1 group $(10 \pm 5, n=8)$ was particularly smaller than in the control ( $p<0.05$, Mann-Whitney $U$ test). This inhibition effect of anti-rhGAL-1 on the regenerating axon population was also clearly seen in the longitudinal sections (Fig. $5 C$ ). Electron microscopy revealed the structural relationship of Schwann cells engulfing regenerating axons. In control groups only a small number of regenerating axons with relatively small diameters were enwrapped by Schwann cells. Macrophages with phagocytosed myelin debris were observed, but no myelinated 

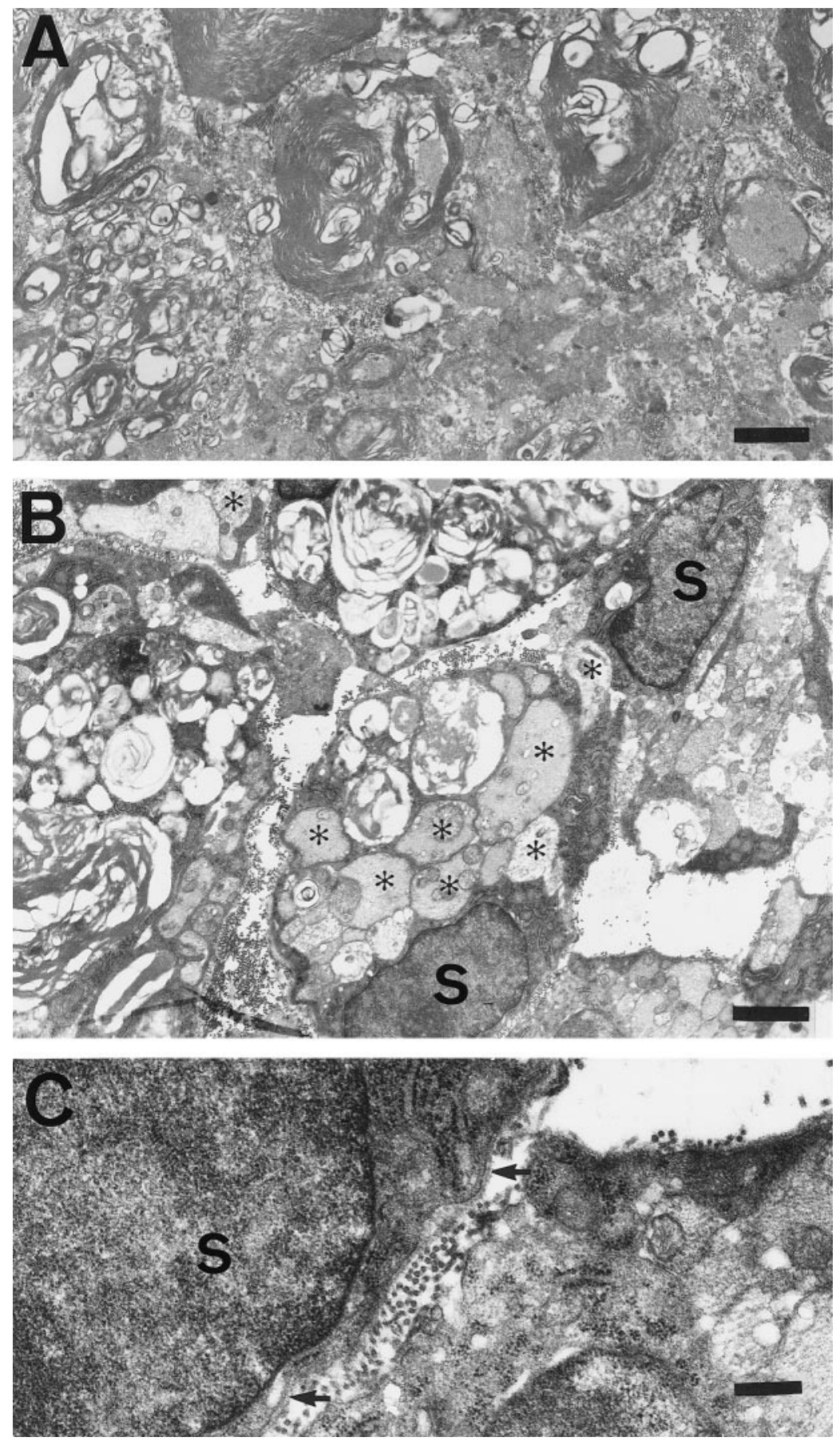

Figure 4. Electron micrographs at a site $6 \mathrm{~mm}$ from the crush lesion at $14 \mathrm{~d}$ after the operation. $A$, Control, showing myelin debris without any reactive Schwann cells or regenerating axons; $B$, rhGAL-1-group, showing several reactive Schwann cells $(S)$ engulfing many regenerating axons $(*)$ among abundant myelin debris; $C$, the enlarged picture of a Schwann cell located in the bottom of $B$. Arrows indicate partially discontinuous basal lamina. Scale bars: $A, B, 2 \mu \mathrm{m} ; C, 0.5 \mu \mathrm{m}$. axons were encountered in these controls (Fig. 6A3). On the other hand, the treatment of rhGAL-1 increased the number of axons together with the number of Schwann cells, some of which enveloped larger axons and started myelination (Fig. 6B3). The appearance of these reactive Schwann cells was comparable to those observed in the crush model. No regenerating axons and Schwann cells could be seen in treatment with anti-rhGAL-1 IgG (Fig. 6C3).

\section{Localization of galectin-1 in regenerating nerve fibers}

The immunohistochemical localization of galactin-1 was examined in serial longitudinal sections of sciatic nerves at $10 \mathrm{~d}$ after the transection. In the case of rhGAL-1 treatment $(5 \mathrm{ng} / \mathrm{ml})$, regenerating axons that extended from the cut edge were immunoreactive for both neurofilament (Fig. 7A) and a growthpromoting cell adhesion molecule, L1 (Fig. $7 B$ ). Many migrating cells that exhibited S-100 immunoreactivity were observed along these regenerating axons, indicating that they were Schwann cells (Fig. 7C). rhGAL-1 immunoreactivity was localized in regions containing Schwann cells and regenerating axons (Fig. 7D). They were confirmed by their HE staining.

\section{DISCUSSION}

Successful nerve regeneration requires the concerted interplay of non-neuronal cells, growth factors, cell adhesion molecules, ex- 

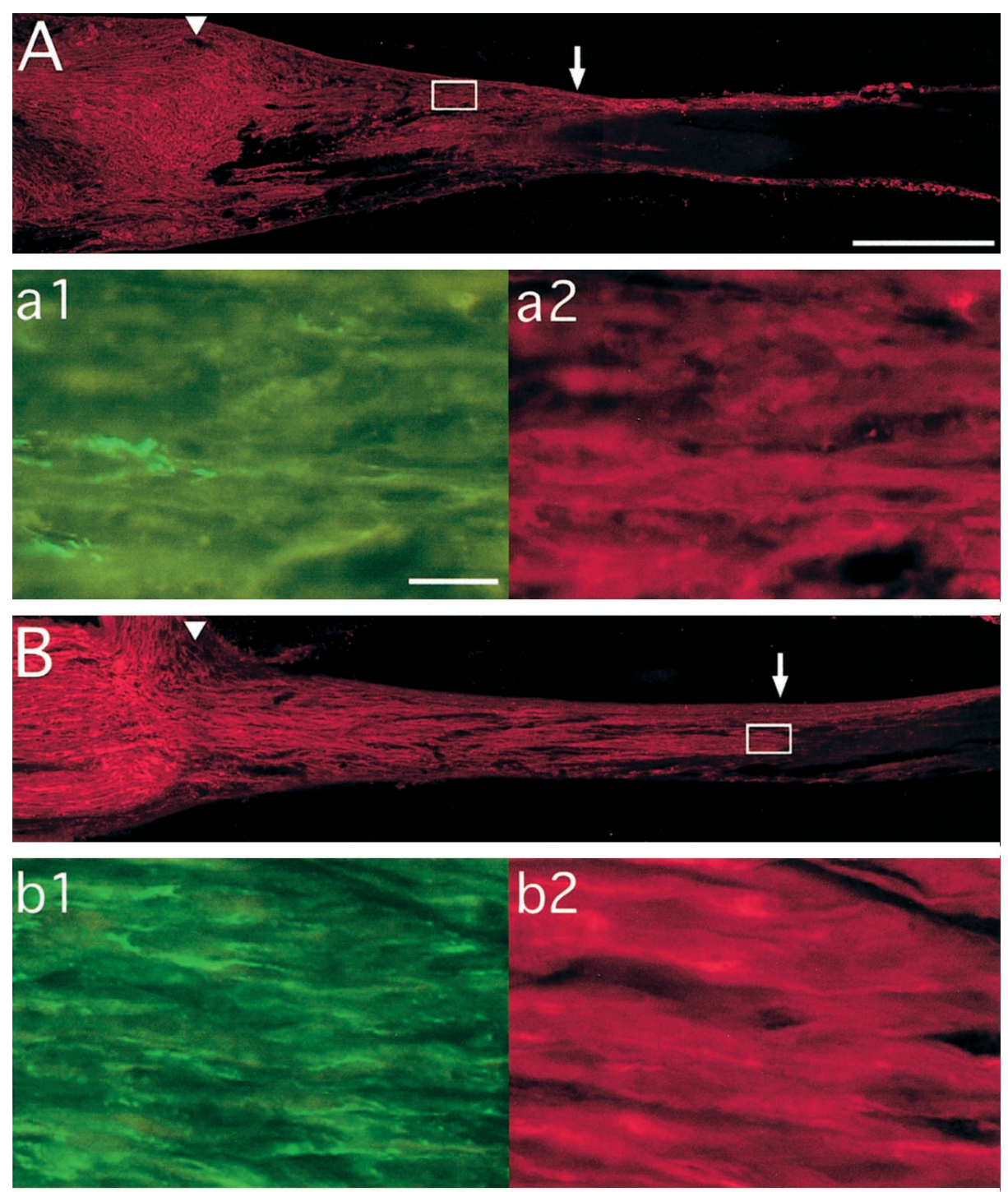

Figure 5. Effect of rhGAL-1 and its antibody on Schwann cell migration and axonal regeneration after nerve transection in vivo. Three different collagen gels were examined: $A$, control; $B$, gel with $5 \mathrm{ng} / \mathrm{ml}$ rhGAL-1; and $C$, gel with $30 \mu \mathrm{g} / \mathrm{ml}$ antibody to rhGAL-1. Animals were fixed $10 \mathrm{~d}$ after the operation. The frozen regenerating tissues were longitudinally sectioned, and the sections were doubleimmunostained with antibody against neurofilaments and S-100. $A, B$, and $C$ were $\mathrm{S}-100-$ stained longitudinal sections. Squares in $A, B$, and $C$ were enlarged to $a 1$ and $a 2, b 1$ and $b 2$, and $c 1$ and $c 2$, respectively. $a 1, b 1, c 1, \mathrm{NF}^{-}$ staining. $a 2, b 2, c 2, \mathrm{~S}-100$ staining. Arrowheads indicate transected edges, and arrows indicate tips of migrating Schwann cells. Scale bars: $A-C, 500 \mu \mathrm{m} ; a 1-c 2,20 \mu \mathrm{m}$.
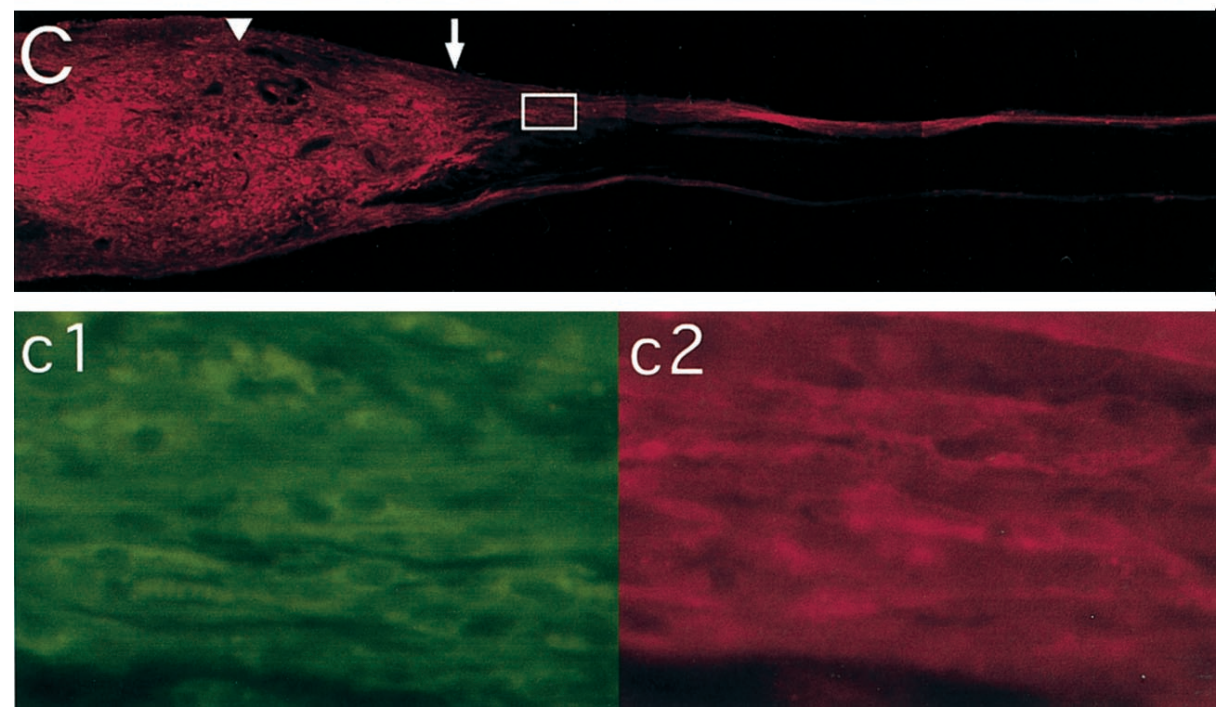

tracellular matrix materials, regenerating axons, and recruiting macrophages (Fawcett and Keynes, 1990; Bunge, 1993, Ide, 1996). However, although various neurotrophins have been demonstrated to promote axonal regeneration in vivo, what factor ini- tiates the response of these members to nerve injury is still not known. Here we presented a member of this interplay, galectin-1, for advancing initial axonal regeneration. To clarify its role in the initial repair, we used two kinds of neural regeneration models: 

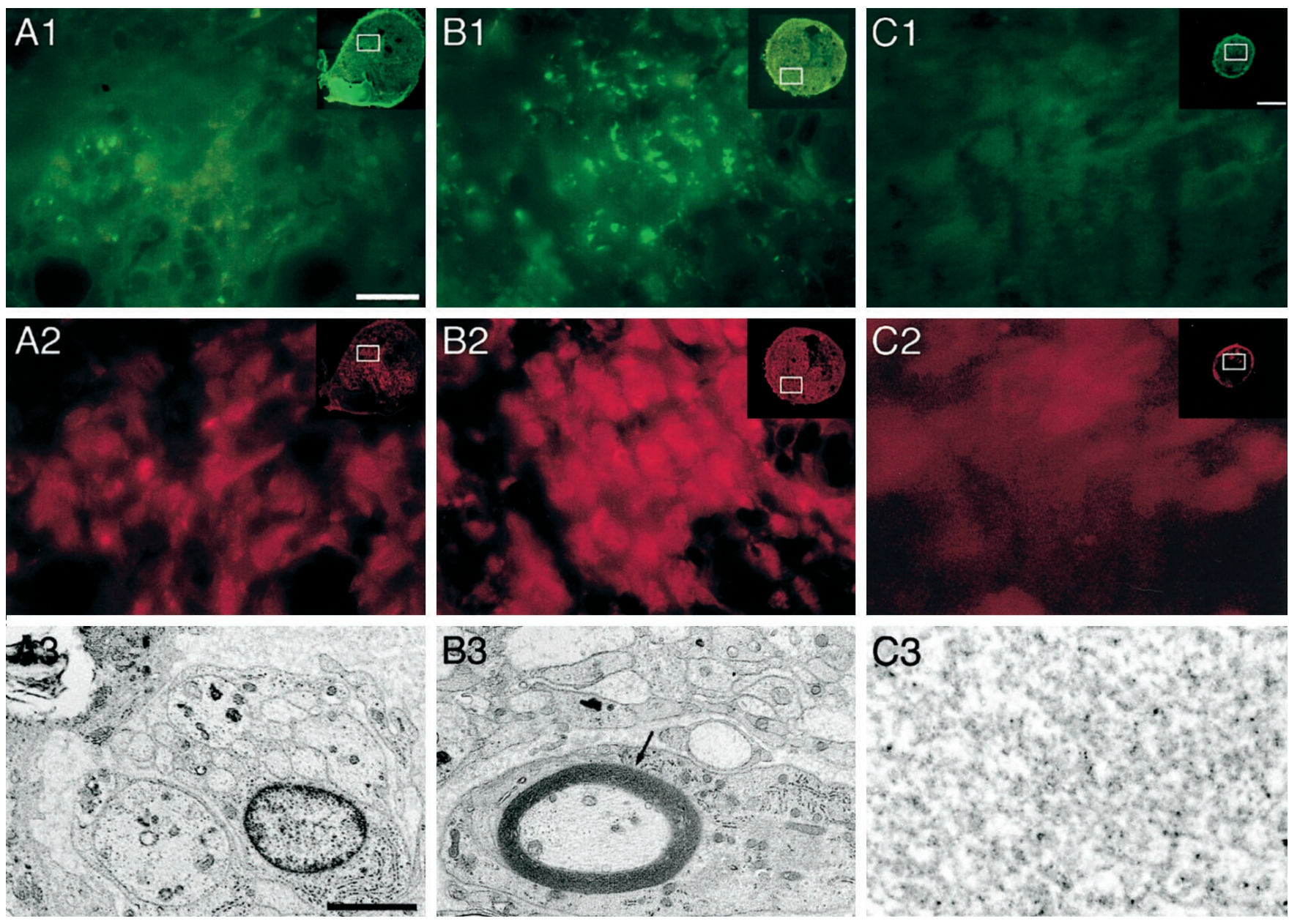

Figure 6. Effects of rhGAL-1 and its antibody on numbers of regenerating axons after nerve transection in vivo. The frozen regenerating tissues obtained by the same procedure in Figure 5 were cross-sectioned $10 \mathrm{~d}$ after operation, and sections $1 \mathrm{~mm}$ distant from a cut edge were doubleimmunostained with antibodies against neurofilaments $(A 1, B 1, C 1)$ and $\mathrm{S}-100(A 2, B 2, C 2)$. These pictures were enlarged from the square in the whole $\mathrm{NF}$-stained cross section shown in the top right corner of $A 1, B 1$, and $C 1 . A 3, B 3$, and $C 3$, Electron microscopic picture of a cross section of grafted collagen gel. $A 1, A 2, A 3$, Control; $B 1, B 2, B 3,5 \mathrm{ng} / \mathrm{ml} \mathrm{rhGAL}-1 ; C 1, C 2, C 3,30 \mu \mathrm{g} / \mathrm{ml}$ antibody to rhGAL-1. A myelinated axon can be seen in $B 3$, indicated by an arrow. Scale bars: $A 1, A 2, B 1, B 2, C 1, C 2,20 \mu \mathrm{m} ; A 3, B 3, C 3,2.5 \mu \mathrm{m}$.

first, a nerve crush combined with freezing of the distal stump, and second, a nerve transection and suture of the proximal stump into a deadend silicon tube. Both in vivo models require extensive participation of non-neuronal cells without any influence of cells in distal sites, because the frozen nerve and the silicone tubes are acellular and disconnected from distal segments. Thus the axonal repair process in proximal sites was precisely analyzed.

\section{Galectin-1 plays a crucial role in the initiation of axonal growth after axotomy}

In the course of degeneration immediately after a transectional injury, proximal axons retract over a distance of several internodal segments and then settle down as the proximal stump. After a brief delay, sprouts begin emerging from the tip of the nerve stump. Our in vitro model suggests that regenerating axons appear without the help of Schwann cells from the transected nerve site (Fig. 1B) (Horie et al., 1991). The similar axonal elongation in the absence of Schwann cells has been revealed in the axonal regeneration into a frozen acellular nerve graft (Ide et al., 1983). However, the signals that prompt the axons to send processes after axotomy are still not known. The signals may be resident endogenous factors that can quickly respond to injury, because the damage induces cells in the injured site to release or secrete them. Galectin-1 is one of the factors. As previous research showed (Regan et al., 1986; Hynes et al., 1990), our immunohistochemical staining for galectin-1 in normal rats revealed immunoreactivity in DRG neurons and their axons as well as in the spinal cord, where motoneurons and their axons were specifically positive. In sciatic nerve, galectin-1-IR was seen not only in axons but also in Schwann cells. Similarly the axons and S-100-positive Schwann cells that had regenerated or migrated into a grafted silicone tube were galectin-1 positive (Fig. 7). As galectin-1 is secreted (Cooper and Barondes, 1990; Barondes et al., 1994) and growth cones bear high exocytosis activity to secrete endogenous molecules (Johnston and Wessells, 1980), the sprouts could secrete galectin-1. Because the factor does not directly work on DRG neurons to promote neurite extension, this secreted galectin-1 could not stimulate sprouts themselves. During this initial stage after axotomy, macrophages invade injured sites that secrete various factors to promote axonal growth or Schwann cell proliferation or Schwann cell secretion of growth factors (Perry, 1994). Under this condition exogenous galectin-1 may stimulate macrophages or other non-neuronal cells to raise 


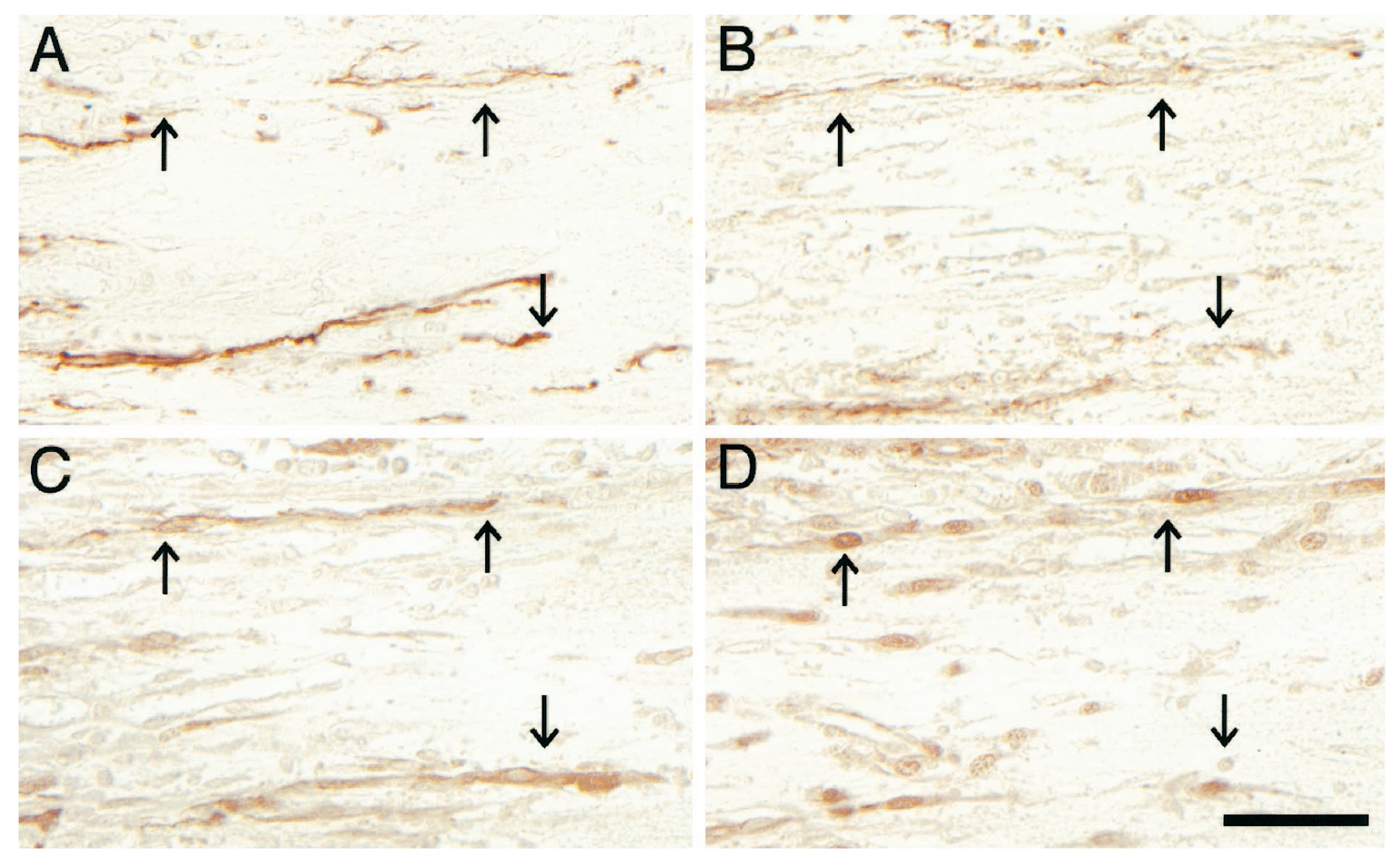

Figure 7. Serial longitudinal sections of the regenerating tissue $10 \mathrm{~d}$ after the transection. Sections were immunostained with anti-neurofilament $(A)$, anti-L1 $(B)$, anti-S-100 $(C)$, and anti-rhGAL-1 $(D)$. After $5 \mathrm{ng} / \mathrm{ml}$ rhGAL-1 treatment, a number of regenerating axons immunoreactive for NF (arrows) extended from the cut edge ( $A$, left side). They were also immunoreactive for L1 ( $B$, arrows). Along the regenerating axons, migrating cells that exhibited S-100 immunoreactivity (arrows) were observed, indicating that they were Schwann cells $(C)$. Intense rhGAL-1 immunoreactivity was observed in regions containing Schwann cells and extending axons (D, arrows). Scale bar, $50 \mu \mathrm{m}$.

the expression level of neurotrophic factors or adhesion molecules, resulting in the advance of axonal regeneration. This axonal elongation into a frozen nerve stump is speculated to induce the comigration of the Schwann cells from the proximal nerve stump (Ide et al., 1983; Fugleholm et al., 1994). Furthermore, the rate of migration or proliferation, or both, of the Schwann cells is thought to become essential and influence the rate of axonal elongation. Figure 7 shows that PCNA-positive Schwann cells in the tip had high mitotic activity and may migrate with proliferation. They also expressed the growth-promoting cell adhesion molecule L1 to help extending their processes along L1-positive regenerating axons resulting from promotion of Schwann cell migration (Fig. 7) (Mirsky et al., 1986; Seiheimer and Schachner, 1988; Wood et al., 1990; Martini, 1994). It is plausible that galecitn-1 regulates initial repair after axotomy in peripheral nerves.

Our crush experiment revealed that galectin-1 enhanced axonal regeneration resulting from the promotion of migration of the reactive Schwann cells (Fig. 4). The same results were clearly seen in the transection experiment. The elongation rate of regenerating axons with the migrating Schwann cells was increased together with an increase in their numbers by the application of galectin-1 (Figs. 5, 6). These accelerations of initial repair by galectin-1 support the possibility that galectin-1 is essential for the initial repair. This possibility was strongly confirmed by the fact that the process was strongly inhibited by the application of anti-galectin- 1 antibody. This antibody may bind the exogenous galectin-1 secreted from regenerating axons to reduce their activities resulting from the strong inhibition of axonal elongation. These results suggest that rhGAL-1 and its antibody may be active in the silicone tubes for the initial stage after operation. It was hard to directly detect galectin-1 in the solution eluted from $5 \mathrm{ng} / \mathrm{ml}$ rhGAL-1 containing collagen gel in the tube (inner volume, $5 \mu \mathrm{l}$ ) by our developed ELISA system capable of detecting $20 \mathrm{pg} / \mathrm{ml}$ galectin-1. However, the characteristics of our tubulization system support the suggestion from our experimental results, which are that (1) large molecules in collagen gel diff use quite slowly, (2) both sides of the tube are sealed, one side by a glass bead and the other side by nerve fibers, (3) rhGAL-1 is stable at $37^{\circ} \mathrm{C}$ for $10 \mathrm{~d}$, and (4) applied rhGAL-1 and its antibody are 100 times more concentrated than their effective concentrations. From these results we conclude that galectin-1 regulates initial repair in peripheral nerves after axotomy.

\section{Galectin-1 may promote axonal regeneration as a factor functioning like a cytokine}

Galectin- 1 is a well characterized $\beta$-galactoside binding animal lectin. This protein exhibits lectin activity only in the reduced form. Galectin-1 has been suggested to play a role in cell adhesion, cell proliferation, or apoptosis in various cells (Perillo et al., 1998). In nervous tissues, galectin-1 is localized in the CNS and PNS in developmental stages, but its distribution is restricted to peripheral nervous tissues with maturation (Dodd and Jessell, 1986; Regan et al., 1986; Hynes et al., 1990). The role of 
galectin-1 in the developing mouse olfactory system has been proved to promote neurite outgrowth and find the olfactory pathway as a lectin under the reduced condition at concentrations higher than $5 \mathrm{ng} / \mathrm{ml}$ (Mahanthappa et al., 1994; Puche and Key, 1995; Puche et al., 1996). However, there have been no reports about the role of galectin-1 in adult mammalian nervous systems. In this paper we proposed the role of galectin- 1 in the adult DRG explants in promoting the axonal regeneration at low concentrations $(50 \mathrm{pg} / \mathrm{ml})$ that are two orders of magnitude lower than those of the lectin activity of reduced galectin-1. It was demonstrated that the molecular structure of galectin-1 was changed under nonreducing conditions resulting from loss of the lectin activity (Tracey et al., 1992; Kasai and Hirabayashi, 1996). Because we exogenously applied rhGAL-1 to the in vivo models as well as the in vitro models under nonreducing conditions, this rhGAL-1 may be oxidized to change its structure and lose the lectin activity. This possibility is supported by the fact that galectin-1 was purified as an axonal regeneration-promoting factor from COS1 cultured supernatant under nonreducing conditions. These observations gave rise to the hypothesis that galectin-1 promotes neural regeneration not as a lectin but as a factor functioning like a cytokine. This hypothesis is confirmed by the treatment with galectin-3, which has a typical lectin activity in solution under nonreducing conditions and promotes neural cell adhesion and neurite growth (Kuwabara and Liu, 1996; Pesheva et al., 1998). It failed to show any promoting activity of axonal regeneration both in our in vitro model $(n=4)$ and in in vivo nerve transection experiments $(n=5)$. These results are consistent with our proposal that galectin- 1 acts not as a lectin but as a cytokine. This work clearly presents one answer to the general question of what role galectin-1 plays in the nervous system (Barondes et al., 1994).

In summary, we purified an axonal regeneration-promoting activity from COS1 cell cultured supernatant and identified the factor as galectin-1. rhGAL-1 confirmed its activity to promote axonal regeneration not only in the in vitro experiment but also in the two kinds of in vivo acellular nerve regeneration models. The high activity of this galectin-1 under nonreducing conditions indicates that it may act as a cytokine and not as a lectin. It is concluded from our experiments that galectin-1 plays an important role in peripheral nerve regeneration. It remains to be shown whether the clinical application of galectin-1 presents a possibility of high functional restoration by a rapid repair to enhance the notoriously slow axonal growth in humans.

\section{REFERENCES}

Apfel SC, Wright DE, Wiideman AM, Dormia C, Snider WD, Kessler JA (1996) Nerve growth factor regulates the expression of brain derived neurotrophic factor mRNA in the peripheral nervous system. Mol Cell Neurosci 7:134-142.

Barde YA, Lindsay RM, Monard D, Thoenen H (1978) New factor released by cultured glioma cells supporting survival and growth of sensory neurones. Nature 274:818.

Barondes SH, Castronovo V, Cooper DNW, Cummings RD, Drickamer K, Feizi T, Gitt MA, Hirabayashi J, Hughes C, Kasai K, Leffler H, Liu F, Lotan R, Mercurio AM, Monsigny M, Pillai S, Poirer F, Raz A, Rigby PWJ, Wang JL (1994) Galectins: a family of animal $\beta$-galactoside-binding lectins. Cell 76:597-598.

Bunge RP (1993) Expanding roles for the Schwann cell: ensheathment, myelination, trophism and regeneration. Curr Opin Neurobiol 3:805-809.

Cooper DNW, Barondes SH (1990) Evidence for export of a muscle lectin from cytosol to extracellular matrix and for a novel secretory mechanism. J Cell Biol 110:1681-1691.

Couraud P-O, Casentini-Borocz D, Bringman TS, Griffith J, McGrogan
M, Nedwin GE (1989) Molecular cloning, characterization, and expression of a human 14-kDa lectin. J Biol Chem 264:1310-1316.

Dodd J, Jessell TM (1986) Cell surface glycoconjugates and carbohydrate binding proteins: possible recognition signals in sensory neurone development. J Exp Biol 124:225-238.

Fawcett JW, Keynes RJ (1990) Peripheral nerve regeneration. Annu Rev Neurosci 13:43-60.

Friedman B, Scherer SS, Rudge JS, Morrisey D, McClain J, Wang DY, Wiegand SJ, Furth ME, Lindsay RM, Ip NY (1992) Regulation of ciliary neurotrophic factor expression in myelin related Schwann cells in vivo. Neuron 9:295-305.

Fugleholm K, Schmalbruch H, Krarup C (1994) Early peripheral nerve regeneration after crushing, sectioning, and freeze studied by implanted electrodes in the cat. J Neurosci 14:2659-2673.

Funakoshi H, Frisen J, Barbany G, Timmusk T, Zachrisson O, Verge VMK, Persson H (1993) Differential expression of messenger RNAs for neurotrophins and their receptors after axotomy of the sciatic nerve. J Cell Biol 123:455-465.

Glazner GW, Lupien S, Miller JA, Ishii DN (1993) Insulin-like growth factor II increases the rate of sciatic nerve regeneration in rats. Neuroscience 54:791-797.

Glazner GW, Morrison AE, Ishii DN (1994) Elevated insulin-like growth factor (IGF) gene expression in sciatic nerves during IGFsupported nerve regeneration. Mol Brain Res 25:265-272.

Hansson HA, Dahlin LB, Danielsen N, Fryklund L, Nachemson AK, Polleryd P, Rozell B, Skottner A, Stemme S, Lundborg G (1986) Evidence indicating trophic importance of IGF-I in regenerating peripheral nerves. Acta Physiol Scand 126:609-614.

Hasegawa M, Rosenbluth J, Ishise J (1988) Nodal and paranodal structural changes in mouse and rat optic nerve during Wallerian degeneration. Brain Res 452:345-357.

Hasegawa M, Yamashima T, Kida S, Yamashita J (1997) Membranous ultrastructure of human arachnoid cells. J Neuropathol Exp Neurol 56:1217-1227.

Heumann R, Lindholm D, Bandtlow C, Meyer M, Radeke MJ, Misko TP, Shooter E, Thoenen H (1987) Differential regulation of mRNA encoding nerve growth factor and its receptor in rat sciatic nerve during development, degeneration, and regeneration: role of macrophages. Proc Natl Acad Sci USA 84:8735-8739.

Horie H, Bando Y, Chi H, Takenaka T (1991) NGF enhances neurite regeneration from nerve-transected terminals of young adult and aged mouse dorsal root ganglia in vitro. Neurosci Lett 121:125-128.

Horie H, Sakai I, Akahori Y, Kadoya T (1997) IL-1 $\beta$ enhances neurite regeneration from transected-nerve terminals of adult rat DRG. NeuroReport 8:1955-1959.

Hynes MA, Gitt M, Barondes SH, Jessell TM, Buck LB (1990) Selective expression of an endogenous lactose-binding lectin gene in subsets of central and peripheral neurons. J Neurosci 10:1004-1013.

Ide C (1996) Peripheral nerve regeneration. Neurosci Res 25:101-121.

Ide C, Tohyama K, Yokota R, Nitatori T, Onodera S (1983) Schwann cell basal lamina and nerve regeneration. Brain Res 288:61-75.

Johnston RN, Wessells NK (1980) Regulation of the elongation nerve fiber. Curr Topics Dev Biol 16:165-206.

Kanje M, Skottner A, Sjoberg J, Lundborg G (1989) Insulin-like growth factor (IGF-1) stimulates regeneration of the rat sciatic nerve. Brain Res 486:396-398.

Kasai K, Hirabayashi J (1996) Galectins: a family of animal lectins that decipher glycocodes. J Biochem 119:1-8.

Koliatsos VE, Clatterbuck RE, Winslow JW, Cayouette MH, Price DL (1993) Evidence that brain-derived neurotrophic factor is a trophic factor for motor neurons in vivo. Neuron 10:359-367.

Kotzbauer PT, Lampe PA, Heuckeroth RO, Golden JP, Creedon DJ, Johnson EMJ, Milbrandt J (1996) Neurturin, a relative of glial-cellline-derived neurotrophic factor. Nature 384:467-470.

Kuwabara I, Liu F-T (1996) Galectin-3 promotes adhesion of human neutrophils to laminin. J Immunol 156:3939-3944.

Levi-Montalcini R, Hamburger V (1951) Selective growth stimulating effects of mouse sarcoma on the sensory and sympathetic nervous system of the chick embryo. J Exp Zool 116:321-362.

Lin L-FH, Doherty DH, Lile JD, Bektesh S, Collins F (1993) GDNF: a glial cell line-derived neurotrophic factor for midbrain dopaminergic neurons. Science 260:1130-1132.

Lindholm D, Heumann R, Meyer M, Thoenen H (1987) Interleukin-1 regulates synthesis of nerve growth factor in non-neuronal cells of rat sciatic nerve. Nature 330:658-659. 
Mahanthappa NK, Cooper DNW, Barondes SH, Schwarting GA (1994) Rat olfactory neurons can utilize the endogenous lectin, L-14, in a novel adhesion mechanism. Development 120:1373-1384.

Martini R (1994) Expression and functional roles of neural cell surface molecules and extracellular matrix components during development and regeneration of peripheral nerves. J Neurocytol 23:1-28.

Mirsky R, Jessen KR, Schachner M, Goridis C (1986) Distribution of the adhesion molecules N-CAM and L1 on peripheral neurons and glia in adult rats. J Neurocytol 15:799-815.

Miura M, Kobayashi M, Asou H, Uyemura K (1991) Molecular cloning of cDNA encoding the rat neural cell adhesion molecule L1: two L1 isoforms in the cytoplasmic region are produced by differential splicing. FEBS Lett 289:91-95.

Perillo NL, Marcus ME, Baum LG (1998) Galectins: versatile modulators of cell adhesion, cell proliferation, and cell death. J Mol Med 76:402-412.

Perry VH (1994) Macrophages in peripheral nerve repair. In: Macrophages and the nervous system. Austin, TX: R. G. Landes.

Pesheva P, Kuklinski S, Schmitz B, Probstmeier R (1998) Galectin-3 promotes neural cell adhesion and neurite growth. J Neurosci Res 54:639-654.

Pu S-F, Zhuang H-X, Ishii DN (1995) Differential spatio-temporal expression of the insulin-like growth factor genes in regenerating sciatic nerve. Mol Brain Res 34:18-28.

Puche AC, Key B (1995) Identification of cells expressing galectin-1, a galactose-binding receptor, in the rat olfactory system. J Comp Neurol 357:513-523.

Puche AC, Poirier F, Hair M, Bartlett PF, Key B (1996) Role of galectin-1 in the developing mouse olfactory system. Dev Biol 179:274-287.

Regan LJ, Dodd J, Barondes SH, Jessell TM (1986) Selective expression of endogenous lactose-binding lectins and lactoseries glycoconjugates in subsets of rat sensory neurons. Proc Natl Acad Sci USA 83:2248-2252.

Rosenbluth J, Hasegawa M, Shirasaki N, Rosen CL, Liu Z (1990) Myelin formation following transplantation of normal fetal glia into myelindeficient rat spinal cord. J Neurocytol 19:718-730.

Seiheimer B, Schachner M (1988) Studies of adhesion molecules mediating interactions between cells of peripheral nervous system indicate a major role for L1 in mediating sensory neuron growth on Schwann cells in culture. J Cell Biol 107:341-351.

Sendtner M, Schmalbruch H, Stšckli KA, Carroll P, Kreutzberg GW, Thoenen H (1992) Ciliary neurotrophic factor prevents degeneration of motor neurons in mouse mutant progressive motor neuropathy. Nature 358:502-504.

Seto A, Hasegawa M, Uchiyama N, Yamashima T, Yamashita J (1997) Alteration of E-cadherin and alpha N-catenin immunoreactivity in the mouse spinal cord following peripheral axotomy. J Neuropathol Exp Neurol 56:1182-1190.

Sjoberg J, Kanje M (1989) Insulin-like growth factor (IGF-1) as a stimulator of regeneration in the freeze-injured rat sciatic nerve. Brain Res 485:102-108.

Tracey BM, Feizi T, Abbott WM, Carruthers RA, Green BN, Lawson AM (1992) Subunit molecular mass assignment of 14.654Da to the soluble-galactoside-binding lectin from bovine heart muscle and demonstration of intramolecular disulfide bonding associated with oxidative inactivation. J Biol Chem 267:10342-10347.

Varon S, Manthorpe M, Adler R (1979) Cholinergic neurotrophic factors. I. Survival, neurite outgrowth, and choline acetyltransferase activity in monolayer cultures from chick embryo ciliary ganglia. Brain Res 173:29-45.

Verge VMK, Riopelle RJ, Richardson PM (1989) Nerve growth factor receptors on normal and injured sensory neurons. J Neurosci 9:914-922.

Wood PM, Schachner M, Bunge RP (1990) Inhibition of Schwann cell myelination in vitro by antibody to the L1 adhesion molecule. J Neurosci 10:3635-3645.

Yan Q, Elliot J, Snide WD (1992) Brain-derived neurotrophic factor rescues spinal motor neurons from axotomy-induced cell death. Nature 360:753-755. 